\title{
YUS 1 IISIA

\section{Human Rights Violation Against the Indonesian Migrant Fisheries Crew in Chinese-Flagged Long Xing Vessel}

Fithriatus Shalihah ${ }^{1}$; Muhammad Nur ${ }^{2}$

${ }^{1,2}$ Faculty of Law, Universitas Ahmad Dahlan

Corresponding author's email: fithriatus.shalihah@law.uad.ac.id

\begin{tabular}{l}
\hline Article Information \\
\hline Submitted : 09 December 2020 \\
Reviewed : 04 March 2021 \\
Accepted : 30 March 2021 \\
Keywords: \\
Indonesian migrant fisheries \\
crew; long xing vessel; \\
human rights violations; \\
legal protection \\
DoI: 10.20961/yustisia. \\
v10i1.46515
\end{tabular}

\begin{abstract}
This paper aimed to analyze human rights violations against migrant fishing boat crews with a case study on the Chinese-flagged Long Xing fishing boat. The research method used is empirical legal research using primary data and secondary data. The results showed that there had been human rights violations experienced by migrant fishing boat crews aboard the Chinese-flagged Long Xing fishing boat. These human rights violations have occurred since the pre-employment phase. The act of dumping the bodies of the crew members of Indonesian ships into the sea in the case of the Long Xing Ship violated the provisions of the ILO Seafarers Regulation Article 30 concerning protocol if the crew of the ship died, also violated Indonesia's national regulations, namely the Minister of Transportation Regulation No. 84 of 2013 Article 18 concerning the protocol for repatriating the bodies of crew members. Therefore, Indonesia's Government needs serious improvements to protect Indonesian fishing boat crews by implementing legal protection regarding their rights both before, during, and after Indonesian migrant fishery crew members work abroad.
\end{abstract}

\section{Introduction}

The definition of vessels crew/crew members is the person employed/hired on board by the owner or operator of the vessel to perform duties on board following the positions listed in the certificate book and/or sea work agreement. One of the crew members was the ship's boat. Based on data from the Directorate of Protection of Indonesian Citizens and Indonesian Legal Entities, Ministry of Foreign Affairs, there were $>200,000$ Indonesian crew members working on foreign fishing vessels during 2013-2015 with the highest placements in Taiwan (217,655 people) and South Korea (31,792 people) (Badan Pengkajian dan Pengembangan Kebijakan Kementerian Luar Negeri Republik Indonesia, 
2016). Meanwhile, the Indonesian Migrant Workers Protection Agency (BP2MI) noted that the number of Indonesian migrants who worked as crew members abroad during 2011-2019 was 30,864 people (Indonesia Ocean Justice Initiative, 2020). In the case of Long Xing fishing vessel that occurs in South Korean sea jurisdiction, 46 vessel crews are Indonesian citizens. The crew of the ship, which numbered 46 people, were stationed on several ships, namely 15 people in Long Xing 629, 8 people in Long Xing 605, 8 people in Long Xing Tian Yu, and 20 people in Long Xing 606 (Afriansyah, 2020).

As Indonesian citizens, crew members are entitled to legal protection, because they are workers protected by law. According to Imam Soepomo, the aim of implementing social justice in the field of manpower and its implementation is to protect workers from the unlimited power of the employer (Soepomo, 2003).

Protection of ship crews has been regulated in Indonesian national legislation and international law. The legislation for Indonesian migrant fisheries crew which is regulated in Regulation of the Minister of Transportation Number 84 of 2013 Concerning Recruitment And Placement Of Crew, Law Number 13 of 2003 Concerning Manpower and Law Number 18 of 2017 Concerning The Protection Of Indonesian Migrant Workers. Besides, international law has also been arranged on the protection of the crew of migrant fishery vessels, consisting of:

1. Work in Fishing Convention 2007

2. International Convention on Standards of Training, Certification and Watchkeeping for Fishing Vessel (STCW-F) 1995

3. Seafarer's Identity Documents Convention 2003

4. Recruitment and Placement of Seafarers Convention 1996

5. Repatriation of Seafarers Convention (Revised) 1987

6. Health Protection and Medical Care (Seafarers) Convention 1987

7. Minimum Age (Fishermen) Convention 1959

8. Seafarers Hours of Work and the Manning of Ships Convention 1996

9. Accommodation of Crews (Fishermen) Convention 1966 and Accommodation of Crews (Supplementary Provisions) Convention 1970

10. Social Security (Seafarers) Convention (Revised) 1987

11. Safety Recommendations for Decked Fishing Vessels of Less than 12 metres in Length and Undecked Fishing Vessels

12. Cape Town Agreement on Safety of Fishing Vessels 2012 (Nur, 2018).

Meanwhile, the number of Indonesian fishers who experience criminal cases while engaging in working relations abroad, in terms of employment is around $48 \%$, and human trafficking is around $12 \%$. And the condition also triggers the practice of labour violations, forced labour, human smuggling, and trafficking criminal acts (International Organization for Migration, et al, 2016).

Based on the BP2MI data source in 2020, wages are not paid is the reason for the most common cause of complaint Indonesian migrant Fisheries Crew to BP2MI. Among 
the many complaints such as a death in other countries, accidents, repatriation problem, the detention of documents by the Indonesian migrant workers supplier, migrant workers who fail to depart, Indonesian migrant workers in custody/detention processes, inappropriate work, fraud job opportunities, and others (BP2MI, 2020).

Global Slavery Index data (slavery in the labour sector) predicts 1,220,000 Indonesian workers estimated into slavery both in and outside the country. This data is a severe case, where the act of slavery is a category of humanitarian crimes that are not justified and must be eradicated (Global Slavery Index, 2019).

The case that occurred against the Indonesian crew working on the Chinese-flagged Long Xing ship due to the actions of human rights violations such as exploitation, human trafficking, modern persecutions and slavery. The case unfolded after a video of which 3 Indonesian ships crew who passed away were allegedly due to severe persecution and his body was disposed to the sea of South Korea's jurisdiction.

Based on reports and testimonies of the surviving Indonesian migrant fisheries crew, which amounted to 48 people, describing the occurrence of human rights violations committed by the Chinese crew against the Indonesian ship crews. They admit to being persecuted, their passport seized by the ship captain, they should drink water from the water distillation that is not worthy of consumption and to trigger health disorder for Indonesian migrant fisheries crew. The phenomenon of various violations of the law is the reason the author conducts legal research titled human Rights violations against migrant fisheries crew (a case study of the Chinese flag Long Xing ship)

\section{Research Methods}

The type of research method used by the authors is empirical legal research by using primary data and secondary data. Primary Data is obtained by conducting interviews with several respondents consisting of:

1. Deputy of Placement of Indonesian Migrant Workers Protection Agency (BP2MI)

2. Head of the Database Section, Case Analysis and Legal Aid, Directorate of Protection of Indonesian Citizens and Indonesian Legal Entities, Ministry of Foreign Affairs of Indonesia

3. The executive director of Migrant Care Indonesia.

The secondary data used by the authors includes primary legal materials which are national and international regulations relating to human rights and the protection of migrant fishery crew members. The author also uses secondary legal materials from literature searches and previous research results as well as tertiary materials to define terms.

\section{Result and Discussion}

Cases of human rights violations committed by Chinese crew members against Indonesian crew members on the Long Xing boat in South Korean waters has been investigated. Based on the report on the General Crime of the Police of the Republic of 
Indonesia and also from the data from the Ministry of Foreign Affairs, 46 Indonesian migrant fisheries crew are stationed consisting of 15 Indonesians on the Long Xing 629 ship, 8 Indonesians on the Long Xing 605 ship, 3 Indonesians on the Tian Yu ship, and 20 Indonesian citizens on the Long Xing 606 ship. A total of 14 crew members have been sent home, and four crew members died whose bodies were dumped into the sea. The four Indonesian migrant fisheries crew ships died due to the treatment of physical abuse and exploitation carried out on the Long Xing ship. It is a case of a human rights violation that shows sufficient legal protection against the crew of Indonesian migrant fisheries. Human rights violations experienced by Indonesian fishing crew, in this case, have been started since before the crew were deployed.

In this case, the principle is a fundamental mind, abstract and is a concrete thing in a particular legal system, the principle of law, in that case, is a philosophical basis, speaking in terms of the principle of international law, it becomes a basis of the obligation of the state in protecting human rights, as well as the principle of pacta sunt servanda and exhaustion principle of local remedies and it is a principle of state responsibility in ensuring human rights protection.

The concept of human rights theory based on the history of the idea of human rights thought is derived from the theory of natural rights (natural rights theory) which gives the conclusion that human rights exist and are owned by a person because of his nature as a human being, the theory of natural rights also contributes importantly to the recognition of human rights, the theory calls for and affirms to protect human rights to every human being, and also the theory provides space for guarantees and support in a human rights protection system both at the domestic and international level (Callaway, 2007), in the theory of natural rights also gives the highest achievement of the right of the natural is the recognition of human beings as individuals and subjects in the legal and social system of society, in which case human rights are inherent natural rights and can not be revoked by anyone (Nowak, 2003).

In this case, with the discovery of the theory of natural rights every country is required to protect and uphold human rights both domestically and outside its territory which this imposes obligations on the state so that whatever the state does is solely to protect the natural rights of each individual such as the right to life, security, and others, protection of the human rights of each individual is handed over to the state, if the ruler of the state ignores and violates the natural rights of the individual, then the people of the country are free to overthrow the ruler and replace him with a government that respects those rights (Rahayu et al., 2013).

Whereas it is very clear that human rights condemn all forms of actions that lead to the freedom and torture of a person[8].Human rights are a person's absolute right where the idea of human rights states that every individual has the right to claim his/her freedom legally and no one can claim that right. Although human rights are not an equal justice or "good society", but human rights is a representation of the state's concern for the life and life of a person in which there is a moral value and the right of a person to live life in order to live life as desired [9].Violations against Indonesian fishing vessel crews can be seen from the recruitment process with unclear procedures, personal documents 
held by the Worker's Agent, the collection of recruitment fees from prospective workers, and others. This condition results in exploitation actions against Indonesian migrant fishery crews. Table 1 shows data from BP2MI regarding recapitulation of complaints from ship crew from 2018 to 6 May 2020.

Table 1. Recapitulation of Ship Crew Complaints for the Period 2018 to May 6, 2020.

\begin{tabular}{|c|c|c|c|c|}
\hline Complaint Status & 2018 & 2019 & 2020 & Total \\
\hline $\begin{array}{l}\text { Complaints In } \\
\text { Process }\end{array}$ & 10 & 98 & 39 & 147 \\
\hline $\begin{array}{l}\text { Complaint } \\
\text { Completed }\end{array}$ & 149 & 112 & 3 & 264 \\
\hline $\begin{array}{l}\text { Number of } \\
\text { Complaints }\end{array}$ & 159 & 210 & 42 & 411 \\
\hline $\begin{array}{l}\text { Registered in } \\
\text { SIUPPAK }\end{array}$ & 19 & 26 & 9 & 54 \\
\hline $\begin{array}{l}\text { Not Registered in } \\
\text { SIUPPAK }\end{array}$ & 103 & 170 & 33 & 306 \\
\hline Without P3MI & 37 & 14 & 0 & 51 \\
\hline Total & 159 & 210 & 42 & 411 \\
\hline
\end{tabular}

Source: BP2MI, 2020.

Work situations and exploitation of Indonesian migrant fisheries crew members that often occur, such as salaries/wages that are too small or even not paid at all, so that they are not in accordance with the work agreement agreed with the crew at the beginning. This condition causes the right to get a decent wage for workers, which is a right protected by the Indonesian constitution, not fulfilled. This matter violates the provisions of ILO convention no. 100 of 1951 concerning Equal Remuneration. Also, the work activities and working hours of Indonesian migrant fishery crew members who work on the Long Xing Fish boat are inhuman, where they are forced to work up to 18 hours a day without taking a break. It is also a violation of human rights, in this case, namely the personal human right not to be coerced and tortured. Besides, the contents of the work contract or the Sea Work Agreement are not up to standard, where the right to insurance coverage is not provided so that it violates the economic rights of Indonesian fishery crew members and violates the provisions of ILO Convention No. 102 concerning Minimum Standards for Social Security.

In terms of national regulations, the Minister of Transportation Regulation No. 84 of 2013 concerning the Recruitment and Placement of Ship Crew, Article 11 has been regulated regarding the quality management system of shipping agents. The article provides that the agency company is responsible for the ship's crew that is placed, starting from the signing of the sea work agreement until the crew returns to the first place of departure.

However, in reality, the recruitment procedures for Indonesian migrant fisheries crew members are often carried out in violation of the rules. Violations that occurred 
such as the agency not provide education and training for crew members, the risks that occur to crew members are hidden, there is no monitoring of crew members employed by crew agents, and retaining of crew personal documents ship like a passport by the agency company. Thus, the crew of the Indonesian migrant fishing boat experience exploitation while working. Inadequate recruitment processes resulting in exploitation of employment opportunities and human rights violations have started before departure (Nur \& Susanto, 2021).

Based on data from the Directorate of Protection of Indonesian Citizens (Ministry of Foreign Affairs), the crew of Indonesian fishing vessels in the case on the Long Xing ship show many workers leave for work without legal procedures (undocumented) and do not have a sea work agreement according on the Minister of Transportation Regulation No. 84 of 2013. This is an essential issue in the protection of Indonesian fishing crews abroad. The reason is, the impact of the absence of data on Indonesian crew members is an obstacle in the supervision of Indonesian citizens who leave the country to look for work as well as become crew members of fishing vessels on foreign ships. However, according to the author, regardless of whether the crew of Indonesian fishing vessels departed through legal routes or not, their position as Indonesian citizens, wherever they worked, the state was obliged to provide protection.

According to the Deputy for Placement of the Indonesian Migrant Workers Protection Agency, stated that the handling of cases of Indonesian fishery crew members working on foreign ships in foreign waters is often more complicated and takes a long time. This matter is influenced by the challenges faced today, namely (Indonesia Ocean Justice Initiative, 2020):

1) Regulations for the placement and protection of Indonesian fisheries crews are not yet harmonious.

2) There has not been a synergy in the division of authority and coordination between related agencies in Indonesia.

3) There has been no integration and synchronization of the database for the placement of Indonesian migrant fishing boat crew abroad (Nur, 2018).

According to the author, the government should not have to shift responsibility because the data on the crew of Indonesian migrant fishing vessels have not been integrated. The development of very sophisticated technology nowadays allows all existing data in each related institution to be adequately integrated so that the government's reason is not quite right.

The ILO convention regarding the legal protection of crew members who work on foreign ships, especially fishing vessels, has been regulated in ILO Convention No. 188 of 2007 concerning Work in Fishing. The convention is standardization of legal protection for migrant fishing boat crews on fishing vessels internationally. But unfortunately, until now Indonesia has not ratified the convention (Nur, 2018).

Nixson Silalahi, Assistant Deputy for Maritime Law and Treaties at the Coordinating Ministry for Maritime Affairs and Investment, said Indonesia on 7 May 2019 had agreed that at that time Government was not ready to ratify ILO Convention No. 188. But, the Government will prepare for ratification by optimizing the implementation of national

72 Yustisia Volume 10 Number 1 (Jan-Apr 2021)

Human Rights Violation Against... 
regulations that adopt the provisions of the convention (Humasindonesia.id, 2020). However, according to the author, the government's attitude that is not responsive to being a party to this international agreement is not quite right. Supposedly, as a member of the United Nation and also as part of the world community whose citizens also carry out work in the jurisdictions of other countries, Indonesia also has an interest in ratifying the convention. Because it is not impossible that human rights violations against migrant fishing boat crews from other countries and Indonesian fishing boat crews also become victims in cases of law violations that occur in the jurisdiction of Indonesia, besides, the content of the convention also regulates the recruitment standards for fishery boat crew candidates that domestic actors must comply with. Therefore, the government should be in good faith to ratify ILO Convention No. 188 in 2007. Some of the provisions in ILO Convention No. 188 of 2007 that are relevant for the protection of Indonesian migrant workers on fishing vessels are shown in the table 2.

Table 2. Several Provisions of C-188 are Relevant for the Protection of Indonesian Migrant Workers on Fishing Vessels.

\begin{tabular}{|c|c|}
\hline Articles & Contents \\
\hline $\begin{array}{l}8 \text { (Responsibilities } \\
\text { of Fishing Vessel } \\
\text { Owners, Captain } \\
\text { and Crew) }\end{array}$ & $\begin{array}{l}\text { - The captain must ensure that the crew is in the best safety and } \\
\text { health conditions. } \\
\text { - The captain must treat the crew members with respect for } \\
\text { their safety and health }\end{array}$ \\
\hline 14 (Rest Period) & $\begin{array}{l}\text { The minimum rest period should not be less than } 10 \text { hours/day } \\
\text { and } 77 \text { hours/ } 7 \text { days }\end{array}$ \\
\hline $\begin{array}{l}\text { 16-20 (Standard } \\
\text { Sea Labor } \\
\text { Agreement) }\end{array}$ & $\begin{array}{l}\text { Standard Sea Work Agreements must include the amount of } \\
\text { wages, total time off, health and social security protection, crew } \\
\text { rights, and minimum rest periods. }\end{array}$ \\
\hline $\begin{array}{l}22 \text { (Recruitment } \\
\text { and Placement) }\end{array}$ & $\begin{array}{l}\text { Require the state to make regulations for the manning agency: } \\
\text { exemption from recruitment fees, administrative sanctions for } \\
\text { permits if there is a violation. }\end{array}$ \\
\hline
\end{tabular}

Source: ILO Convention No. 188 of 2007 (processed).

The essential provisions contained in the ILO Convention No. 188 of 2007, such as:

1. The responsibilities of fishing vessel owners and boat masters regarding fisherman safety on board and ship security.

2. Minimum age for workers to work on fishing boats.

3. Skipper's competence to steer the ship.

4. Social security that protects against disease, periodic health checks and job protection.

5. Wage arrangements.

6. Work protection agreement and requirements regarding the work to be performed (ILO, 2007).

In the case of exploitation of Indonesian crew members on the Long Xing China fishing boat, there were acts of exploitation, unpaid wages and excessive working hours. 
This fact is proof that the crew of the ship are victims of modern slavery. This condition is a violation of human rights, as stated in the Declaration of Human Rights and the ILO Convention Number 1957 concerning the Elimination of Forced Labor.

In this case, it appears that the legal protection of the crew members from Indonesia is very weak, which leads to human rights violations against them. This is in line with the results of previous studies (Nur, 2018) that the weakness of regulation is also the leading cause of Indonesian fishery crew issues, which include:

1. The order of Article 64 of Law Number 18 of 2017 concerning the Protection of Indonesian Migrant Workers has not been issued, which was previously mentioned in Article 28 of Law Number 2004, which was revoked.

2. The different arrangements in the Regulation of the Minister of Transportation Number 84 of 2003 and BNP2TKI Regulation Number: PER.12/KA/IV/2013 are related to the form of companies that have the right to implement the placement of fishing boat crew.

3. It is unclear about the central operator institutions in managing the placement and protection of migrant fishing boat crews.

This is the reason for the shifting of responsibilities between government agencies regarding who is most responsible for the protection of Indonesian migrant fishing boat crews both from the pre-work, during work and after work periods. Whereas the country has an important role in providing protection to the workforce that exists abroad as a form of absolute function in the form of (Hanifah, 2020):

1) implement law and order to achieve common goals and prevent from clashing communities

2) strive for prosperity and prosperity to all people

3) defense

4) uphold justice through justice institutions

Human rights violations before the crew of Indonesian migrant fishing vessels work can be caused by weak supervision of companies sending Indonesian migrant workers, violations in the recruitment of fishing boat crews, weaknesses in the stage of providing education or work briefing, the stage of health and psychological examinations, the stage of document processing, violations in maritime work agreements and weaknesses in preventive law enforcement.

The human rights violations that have occurred to the crew of Indonesian fishing boats aboard the Long Xing boat when they are working include: extremely improper wages, physical and verbal violence, working hours that exceed the limit and insufficient rest hours, facilities and fulfillment of basic needs minimal, access to communication are close, retention of relevant documents, health protection that is not provided properly and does not have access to legal assistance. These actions are a violation of human rights that can be categorized as modern slavery.

In this case, the Government needs to continue striving so that the protection of migrant workers can be done. In addition, the government must make efforts to ensure that countries receiving migrant workers from Indonesia ratify the Migrant Workers

74 Yustisia Volume 10 Number 1 (Jan-Apr 2021)

Human Rights Violation Against... 
Convention so that workers receive protection (Agus, 2019). In particular the ILO Convention Number 188 of 2007.

Regulations regarding the recruitment and placement of ship crews in Indonesia have been included in the Regulation of the Minister of Transportation Number 84 of 2013, which regulates 8 Chapters regarding the recruitment and placement of ship crews. The points discussed in the ministerial regulation include:

1. Procedures and licensing procedure

2. Recruitment and placement of crew to the destination or the ship and repatriation

3. Administrative sanctions

4. Settlement of sailor disputes

There are facts of document falsification and the placement and recruitment of Indonesian crew members that are not in accordance with the procedures in the Long Xing ship case. So that based on the Minister of Transportation Regulation No. 84 of 2013 in Chapter 4 regarding Administrative Sanctions, in Article 32 Paragraph 2 Administrative Sanctions stipulates that the sanctions for sending companies are:

1. 3-Time written warning

2. Temporary suspension of business license

3. Revocation of business license

In this case, the Ministry of Foreign Affairs should evaluate and carry out an inspection and urge the Chinese Government to impose legal sanctions to Dalian Ocean Fishing Co., Ltd as the owner of the ships Long Xing 629, Long Xing 605, Long Xing 802, and Tian Yu 8. Apart from that, the Ministry of Foreign Affairs must also make diplomatic efforts to the Chinese government regarding the case and insist that the case on the long xing ship be handled entirely.

The Ministry of Transportation also needs to carry out inspection and evaluation so that it can impose administrative sanctions in the form of revocation of the crew recruitment business license (SIUPPAK) based on Article 33 Paragraph 2 the Minister of Transportation Regulation No. 84 of 2013 if it is right and there is evidence of document forgery, collection of crew recruitment fees and placement of migrant fishing boat crews on the Long Xing ship.

The case of Indonesian crew members on foreign fishing vessels with Chinese flags is not the first case that has happened to Indonesian crew members. Similar cases also often occur, such as in the case of trafficking and exploitation experienced by Indonesian crew members in 2012. In this case, 154 Indonesian crew members have been trafficked on 4 Taiwan fishing boats, and they were successfully returned to Indonesia after being found stranded by local residents in the waters of Trinidad and Tobago. The case was legally resolved in 2015 after it became the public spotlight, and the victims managed to get restitution / compensation (Yea, 2012). The same treatment also needs to be applied to the victims of trafficking and exploitation on the China Long Xing ship (Yea, 2012). Other cases occurred on various ships from different countries, as shown in table 3. 
Table 3. Data on Complaints of Ship Crew from Indonesia for the Period 2018 to May 6, 2020.

\begin{tabular}{|c|c|c|}
\hline No & Country & Total \\
\hline 1 & Taiwan & 122 \\
\hline 2 & South Korea & 45 \\
\hline 3 & Peru & 36 \\
\hline 4 & China & 23 \\
\hline 5 & South Africa & 16 \\
\hline 6 & Vietnam & 15 \\
\hline 7 & Namibia & 14 \\
\hline 8 & Fiji Island & 13 \\
\hline 9 & Angola & 10 \\
\hline 10 & Malaysia & 10 \\
\hline 11 & New Zealand & 9 \\
\hline 12 & Others & 8 \\
\hline 13 & Senegal & 7 \\
\hline 14 & Ghana & 5 \\
\hline 15 & Kenya & 5 \\
\hline 16 & Samoa & 5 \\
\hline 17 & Somalia & 5 \\
\hline 18 & Hong Kong & 4 \\
\hline 19 & Indoa & 4 \\
\hline 20 & Panama & 4 \\
\hline 21 & Gabon & 3 \\
\hline 22 & Iran & 3 \\
\hline 23 & Japan & 3 \\
\hline 24 & Suriname & 3 \\
\hline 25 & United Kingdom & 3 \\
\hline 26 & Congo & 2 \\
\hline 27 & Singapore & 6 \\
\hline 28 & Thailand & 2 \\
\hline 29 & United Arab Emirates & 2 \\
\hline 30 & Uruguay & 2 \\
\hline 31 & Bahrain & 1 \\
\hline 32 & Canada & 1 \\
\hline
\end{tabular}

$76 \quad$ Yustisia Volume 10 Number 1 (Jan-Apr 2021)

Human Rights Violation Against... 


\begin{tabular}{|c|c|c|}
\hline No & Country & Total \\
\hline 33 & Central African Republic & 1 \\
\hline 34 & Chile & 1 \\
\hline 35 & Ethiopia & 1 \\
\hline 36 & France & 1 \\
\hline 37 & Iraq & 1 \\
\hline 38 & Lithuania & 1 \\
\hline 39 & Maldives & 1 \\
\hline 40 & Mauritius & 1 \\
\hline 41 & Netherlands & 1 \\
\hline 42 & Nigeria & 1 \\
\hline 43 & Russia & 1 \\
\hline 44 & Spain & 1 \\
\hline 45 & Sri Lanka & 1 \\
\hline 46 & Syria & 1 \\
\hline 47 & Turkey & 1 \\
\hline 48 & Saudi Arabia & 2 \\
\hline 49 & Niue & 3 \\
\hline & Total & 411 \\
\hline
\end{tabular}

Source: BP2MI, 2020.

In the recruitment process, there are irregularities against recruiters such as brokers and private agents. According to the Hasanuddin University Center for Human Rights Studies, they were reporting that recruiters such as brokers or private agents usually deceive prospective workers by not providing them with true and real information about the working conditions that will be live abroad later, this includes their rights and obligations as workers, the salary they get and the actual migration costs that must be borne by prospective workers, which causes prospective workers to sell assets and borrow money from relatives or have to go into debt in advance to brokers or private agents to finance their migration process. According to IOM (U.S. Departement of State, 2012), private recruiters and agents are responsible for more than $50 \%$ of trafficking cases from Indonesians. This fact is also evident from the case of the Indonesian migrant fishing boat crew on the Long Xing ship with irregularities in the recruitment by the PT. MTB and Xianggang Xinhai Shipping Co. Ltd which can be categorized as having carried out human trafficking. Data from BP2MI in table 4 shows the various types of cases that befell fishing boat crews who have complained to BP2MI. 
Table 4. Types of Cases that Have Been Reported to BP2MI for the Period 2018 to May 6, 2020.

\begin{tabular}{|c|c|c|}
\hline No. & Case Category & Total \\
\hline 1 & Salary is not paid & 183 \\
\hline 2 & Died in the destination country & 46 \\
\hline 3 & Accident & 46 \\
\hline 4 & The crew wants to be sent home & 23 \\
\hline 5 & Retention of passports or other documents by P3MI & 20 \\
\hline 6 & The crew failed to leave & 17 \\
\hline 7 & Others & 10 \\
\hline 8 & Termination of employment before the work agreement ends & 9 \\
\hline 9 & Workers in detention/process custody & 8 \\
\hline 10 & Work does not match the work agreement & 8 \\
\hline 11 & Job opportunity scams & 7 \\
\hline 12 & Cut off communication & 5 \\
\hline 13 & Violence from employers & 5 \\
\hline 14 & Workers have an accident & 5 \\
\hline 15 & Died & 4 \\
\hline 16 & Depression/mental illness & 3 \\
\hline 17 & Sick/inpatient workers & 3 \\
\hline 18 & $\begin{array}{l}\text { Accounts payable between prospective migrant workers and } \\
\text { P3MI }\end{array}$ & 2 \\
\hline 19 & Foreign insurance has not been paid & 1 \\
\hline 20 & The workload is too heavy & 1 \\
\hline 21 & The placement fee exceeds the fee structure & 1 \\
\hline 22 & Smuggling of goods & 1 \\
\hline 23 & Sick & 1 \\
\hline 24 & Migrant workers do not get along well with users & 1 \\
\hline \multirow[t]{2}{*}{25} & Migrant workers are unable to work & 1 \\
\hline & Total & 411 \\
\hline
\end{tabular}

Source: BP2MI, 2020.

The crew of the ship has the right to obtain an explanation of their rights and obligations contained in the work agreement. In Law No. 13 of 2003 on Manpower, this provision regulated in Article 1 Point 14 and Article 54 Paragraph 1 Letter (F) which reads:

\section{Article 1 Point 14}

"The employment agreement is an agreement between a worker/labour with an entrepreneur or employer that contains the terms of employment, rights, and obligations of the Parties." 


\section{Article 54 Paragraph 1 letter (F)}

"Employment conditions contain the rights and obligations of employers and employees/workers."

The modern slavery case committed by the Chinese crew against the Indonesian crew members on the Long Xing ship is an act of human rights violations. According to Anti Slavery International, Modern Slavery is someone who is a victim of slavery not in the form of someone else's ownership, but in relation to acts of exploitation and control of someone by others without being able to escape, someone can be said to be in slavery if (Anti-Slavery International, 2018):

1. Forced to work, whether by force, mental or physical threats

2. Owned or controlled by an employer either through threats of harassment, mental or physical abuse

3. To be treated inhumanely like being treated as a commodity, bought and sold as property

4. Do not have the freedom to move.

The act of slavery is a form of violation of human rights that cannot be tolerated. Another definition of modern slavery is that perpetrators of slavery do not feel that they have a victim of slavery, but perpetrators of slavery exploit and treat victims of slavery cruelly, inhumanely, and arbitrarily, for the benefit of the perpetrators of slavery without the freedom to escape. During its development, slavery or slavery is no longer limited to the slave trade, but has changed into several forms, including trafficking in persons, forced labor, bonded labor, child slavery, early/forced marriage and slavery based on descent (Indah Prisnasari, 2019).

There have been many cases of slavery from the past to the present and have had a detrimental effect on people in various countries. Regulations related to slavery have been regulated in current international human rights law instruments in the form of international conventions and declarations. Several sources of international law contain human rights-related arrangements, namely the Universal Declaration of Human Rights 1948 (UDHR), the Rome Statute and the ICCPR. Provisions regarding the prohibition of slavery are contained in Article 4 to Article 5 in UDHR 1948 which reads:

\section{Article 4}

"No one shall be held in slavery or servitude; slavery and the slave trade shall be prohibited in all their forms."

\section{Article 5}

"No one shall be subjected to torture or to cruel, inhuman or degrading treatment or punishment."

In the International Covenant on Civil and Political Rights 1966 or the so-called ICCPRalso govern the prohibition of slavery contained in Article 7 and Article 8 Paragraph 1 which reads: 


\section{Article 7}

"No one shall be subjected to torture or to cruel, inhuman or degrading treatment or punishment. In particular, no one shall be subjected without his free consent to medical or scientific experimentation."

\section{Article 8}

"No one shall be held in slavery; slavery and the slave-trade in all their forms shall be prohibited."

The Rome Statute also regulates slavery, specifically regulated in Article 7. Based on the three international human rights law instruments, it can be seen that the three of them regulate the prohibition of slavery, the prohibition against treating people inhumanly and torture, and the prohibition of forced acts.

Human rights violations that occurred aboard the Long Xing China vessel against Indonesian migrant fishing boat crews can be categorized as acts that violate international law. The existence of several of these articles means that it emphasizes that slavery is a crime against humanity and that the international prohibition on slavery is absolute and there are no exceptions, considering that every human being has the basic right to be free to do something at his will without any threat or coercion from other parties (Hardianti, 2015).

The regulation regarding slavery and trafficking in persons has also been regulated in Indonesian human rights law as contained in the 1945 Constitution of the Republic of Indonesia, Law No. 39 of 1999, Law No. 26 of 2000 and Law No. 21 of 2007 concerning the Eradication of the Crime of Trafficking in Persons. Based on Law Number 21 of 2007, the definition of trafficking contains 3 (three) main elements that are cumulative, namely:

1. Action elements, including the act of recruiting, transporting, moving, hiding or receiving;

2. Elements of means (means) to control victims and elements of purpose, including threats, use of force, various forms of violence, kidnapping, fraud, cheating, abuse of violence or vulnerable positions or giving / receiving or profits to obtain the consent of the person who controls the victim;

3. Elements of purpose include exploitation, at least for prostitution or other forms of sexual exploitation, forced labor, slavery, servitude and organ harvesting (Hidayati, 2012).

In the case of the migrant fishing boat crew on the Long Xing ship, there are indications of trafficking in persons where it was found that the recruitment process for crew members by the distribution agent was not in accordance with procedures, the identity and passports of the crew were detained, and monitoring of the condition of the crew was not carried out. The human trafficking act experienced by the crew of the fishing boat is also included in the act of human rights violations and crimes in the corporate sphere.

80 Yustisia Volume 10 Number 1 (Jan-Apr 2021)

Human Rights Violation Against... 
Regarding the protection of human rights in business activities, there have been guidelines prepared by the United Nations, namely the United Nation Guiding Principles on Business and Human Rights (UNGP) 2011. The guiding principles in the UNGP are to prevent and overcome the negative impacts of business activities on human rights, including:

1. The state's obligation to protect, respect and fulfill human rights and basic freedoms;

2. The role of a business company as a special organ of society that performs special functions, so that it must follow applicable regulations and respect human rights; and

3. The need for rights and obligations compatible with adequate and effective remedy when they are violated.

From the internal perspective of Indonesia, the absence of special regulations that regulate and protect Indonesian migrant fisheries crew is one of the reasons that cases similar to the Long Xing case continue to occur. The government should immediately prioritize the issuance of derivative rules mandated in Article 64 of Law Number 18 of 2017 concerning the Protection of Indonesian Migrant Workers. The absence of this regulation causes the unclear main ministry/agency that has the authority to regulate the management of migrant fishing boat crew placement so far. Moreover, the absence of this regulation is a gap for those who have been seeking personal gain at the expense of human rights of migrant workers or prospective migrant workers who work as crew on fishing vessel.

\section{Conclusion}

In the case of human rights violations against Indonesian migrant fishing boat crews on the Long Xing China ship, such as persecution, unpaid wages, inhuman working hours, drinking distilled sea water, etc., constitute violations of human rights that violate Indonesian laws and regulations and international conventions. The recruitment process that is not in accordance with the procedure results in work exploitation and human rights violations. Lack of protection, monitoring, and legal certainty for crew members by the Indonesian government, due to the fact that the competent authorities are still shifting responsibility and the data on fishing boat crews has not been integrated in several related ministries/institutions. In addition, Indonesia has not yet ratified ILO Convention No. 118. The government still considers that the ratification of this convention is not urgent because more cases of human rights violations are in the jurisdiction of other countries. In fact, the contents of the convention can become a standard for the placement process for fishing boat crews, starting from recruitment to repatriation.

\section{Acknowledgements}

Thank you, the writer conveyed to the Chancellor of Ahmad Dahlan University, Dr. Muchlas, MT., Dean of Faculty of Law of Universitas Ahmad Dahlan, Head of Research and Community Service Division of Universitas Ahmad Dahlan, and all parties who helped complete this paper which cannot be mentioned one by one. 


\section{BIBLIOGRAPHY}

\section{Books}

Badan Pengkajian dan Pengembangan Kebijakan Kementerian Luar Negeri Republik Indonesia. (2016). Strategi Perlindungan dan Penanganan Kasus Anak Buah Kapal $(A B K)$ Sektor Perikanan Indonesia yang Bekerja di Luar Negeri. Kementerian Luar Negeri Republik Indonesia: Jakarta.

Callaway, R. L. (2007). Exploring International Human Rights: Essensial Readings. Lynne Rienner Publisher: United State of America.

Nowak, M. (2003). Introduction to the International Human Rights Regim. Martinus Nijhoff Publisher: Leiden.

ILO. (2007). Decent Working Conditions, Safety, and Social Protection. Social Dialogue, Labour Law, Labour Administration and Sectoral Activities Department International Labour Office: Geneva.

Soepomo, I. (2003). Pengantar Hukum Perburuhan. Djambatan: Jakarta.

\section{Journals \& Reports}

Afriansyah, A. (2020). Legal Protection for Indonesian Fishing Crews Being Abused at Sea. Asia-Pacific Journal of Ocean Law and Policy, 5(2), 398-402. doi: https://doi. org/10.1163/24519391-05020013

Agus, D. (2013). Kedudukan Konvensi ILO Sebagai Sumber Hukum Perburuhan/ Ketenagakerjaan Indonesia. Jurnal Hukum Internasional, I (1).

BP2MI. (2020). Data Penempatan dan Pelindungan PMI Periode Maret 2020. Pusat Data dan Informasi BP2MI: Jakarta.

Global Slavery Index. (2018). The Global Slavery Index 2018. Walk Free Foundation. Nedlands.

Hanifah, I. (2020). Peran Dan Tanggung Jawab Negara Dalam Perlindungan Hukum Tenaga Kerja Indonesia Yang Bermasalah Di Luar Negeri. DE LEGA LATA: Jurnal Ilmu Hukum. https://doi.org/10.30596/dll.v5i1.3303

Hardianti, S. D. (2015). Modern Slavery in Indonesia: Between Norms and Implementation. Brawijaya Law Journal: Journal of Legal Studies, 2(1).

Hidayati, M. N. (2012). Upaya Pemberantasan dan Pencegahan Perdagangan Orang Melalui Hukum Internasional dan Hukum Positif di Indonesia. Jurnal Al-Azhar Indonesia Seri Pranata Sosial, 166-167.

Indonesia Ocean Justice Initiative. (2020). Perbaikan Tata Kelola Pelindungan ABK Indonesia di Kapal Ikan Asing, Policy Brief 3 June 2020. ICJI: Jakarta.

International Organization for Migration, Kementerian Kelautan dan Perikanan Conventry University. (2016). Laporan mengenai Perdagangan Orang, Pekerja Paksa, dan Kejahatan Perikanan dalam Industri Perikanan di Indonesia. International Organization for Migration in Indonesia: Jakarta. 
Prisnasari, Indah. (2019). Modern Slavery Pada Anak Buah Kapal (ABK) Perikanan Dalam Perspektif Hak Asasi Manusia. Jurist-Diction, 2(2).

Nur, M. (2018). Recommendation for Authorization Overlaping of Placement of Indonesian Fishing Vessels Crews Abroad. Jurnal IUS Kajian Hukum Dan Keadilan, $6(1)$.

Nur, M., Susanto, M. H. (2021). Certification of Fisheries Human Rights and Its Impact to Protecting the Rights of Fishing Vessel Crew. Legality: Jurnal Ilmiah Hukum, 29(1).

Rahayu, S. L., Muslimah, S., \& Sasmini. (2013). Perlindungan HAM Pekerja Migran: Kajian Normatif Kewajiban Indonesia berdasar Prinsip-Prinsip dan NormaNorma Hukum Internasional. Yustisia Jurnal Hukum. https://doi.org/10.20961/ yustisia.v2i1.11082

Yea, S. (2012). Troubled Waters: Trafficking of Filipino men into the long haul fishing industry through Singapore. Transient Workers Count Too: Singapore.

\section{Internet}

Anti-Slavery International. (2018). What is Modern Slavery? Retrivied from https:// www.antislavery.org/slavery-today/modern-slavery/ accessed on 14 August 2020.

Humasindonesia.id. (2020). Percepat Ratifikasi Konvensi ILO No. 188, Pemerintah Ingin Lindungi Awak Kapal Perikanan. Retrivied from https://humasindonesia.id/ agenda/ppid/page/profil/profil/opini/video/wawancara/agenda/berita/ percepat-ratifikasi-konvensi-ilo-no-188-pemerintah-ingin-lindungi-awak-kapalperikanan-342 accessed on 24 December 2020.

U.S. Departement of State. (2012). Trafficking in Persons Report 2012. Retrievied Http:// www.state.gov/j/tip/rls/tiprpt/2012/ accessed on August 8, 2020. 